DOI: $10.19195 / 2300-7729.37 .12$

\author{
ALICJA URBAN \\ ORCID: 0000-0002-7024-5551 \\ Uniwersytet Wrocławski
}

\title{
Współczesna książka interaktywna dla dzieci na przykładzie twórczości Hervé'a Tulleta
}

\section{Wstęp}

Rynek książki dziecięcej w ostatnich latach rozwija się bardzo dynamicznie. Na księgarskich półkach możemy zaobserwować pozycje, które nie mieszczą się w kategorii typowej książki obrazkowej ${ }^{1}$. Ciekawe rozwiązania edytorskie, stosowanie niestandardowych tekstur, narzędzi i form otworzyło nowe pola do dyskusji zarówno wśród bibliologów, pedagogów, teoretyków literatury, jak i znawców sztuki. Książka obrazkowa, a zwłaszcza książka obrazkowa dla dzieci, może być analizowana pod wieloma względami i stać się przedmiotem badań w różnych dyscyplinach naukowych. Być może dlatego książka interaktywna współcześnie jest pomijana i nieco zapominana przez badaczy — ustępuje miejsca nowym technologiom, aplikacjom i multimedialnym propozycjom wydawców.

\section{Problemy z definicją książki interaktywnej}

Interaktywne książki są pierwszym krokiem do budowania nawyków czytelniczych u dzieci. Charakteryzują je nietypowe tekstury, ruchome elementy i kształty, które pozwalają zaciekawić dziecko, włączyć w lekturę oraz pomóc w rozwoju sensorycznym ${ }^{2}$. Interaktywne książki wymagają zaangażowania, interakcji ze strony czytelnika. Mogą działać dzięki wykorzystaniu nowoczesnych

1 M. Cackowska, Czym jest książka obrazkowa? O pojmowaniu ksiązki obrazkowej w Polsce - czesść I, „Ryms” 2009, nr 5, s. 5.

${ }^{2}$ H. Kaplan, Using interactive books to support early literacy skills, https://www.kaplanco. com/ii/using-interactive-books [dostęp: 10.03.2018]. 
technologii lub stosować rozwiązania edytorskie, które zaciekawią dziecko formą książki jako przedmiotu. Książki interaktywne służą wywołaniu pewnych zachowań i reakcji u dzieci, pobudzaniu kreatywności ${ }^{3}$. Często wiąże się to z wykonywaniem zadań, dorysowywaniem kształtów na stronach, odtwarzaniem odgłosów według poleceń spisanych przez autora. W książkach interaktywnych dziecko bierze aktywny udział w „,czytaniu” — nie tylko poprzez słuchanie czytanej przez rodzica czy opiekuna treści, ale często za sprawą możliwości samodzielnego decydowania o narracji, przebiegu wydarzeń.

W polskim dyskursie badawczym nie ma jasnej definicji książki interaktywnej. W specjalistycznych źródłach informacji z zakresu bibliologii, takich jak Encyklopedia wiedzy o książe $e^{4}$ czy Encyklopedia książki ${ }^{5}$, termin ten nie istnieje. Podobnie w wypadku źródeł ogólnych — ani w Encyklopedii popularnej $P W N^{6}$, ani w Słowniku języka polskiego $P W N^{7}$ nie znajdziemy hasła dotyczącego książki interaktywnej. Nawet za granicą, gdzie termin ten jest bardziej powszechny, brakuje fachowej, jednoznacznej definicji. Przykładowo, Michael Robb w swojej pracy New Ways of Reading: The Impact of an Interactive Book on Young Children's Story Comprehension and Parent-Child Dialogic Reading Behaviors ${ }^{8}$, pisząc o wpływie książki interaktywnej, tłumaczy, że może ona stanowić podstawę do nauki czytania, pisania oraz angażowania dzieci i budowania u nich nawyków czytelniczych ${ }^{9}$. W następnym zdaniu daje jednak do zrozumienia, że książka interaktywna nie jest książką drukowaną, a więc pozostaje jedynie w obszarach zainteresowań nowych technologii: „As with print book reading, parental involvement during interactive book reading may be especially helpful in building children's early literacy skills"10.

Zmiany następujące w obrębie książki obrazkowej, a jednocześnie książki interaktywnej, zdają się być pomijane przez księgoznawców. Najbliżej sformułowania definicji, która nie pociąga za sobą związku z nowymi technologiami, są nienaukowe publikacje entuzjastów książki obrazkowej. Allie Wier w artykule Multi-sensory interactive books ${ }^{11}$ pisze, że książki interaktywne są podgatunkiem

${ }^{3}$ Interactive children's book, https://en.wikipedia.org/wiki/Interactive_children $\% 27 \mathrm{~s}$ _book [dostęp: 10.03.2018].

4 Encyklopedia wiedzy o książe, red. A. Birkenmajer, B. Kocowski, J. Trzynadlowski, Wrocław 1971.

5 Encyklopedia ksiażki, red. A. Żbikowska-Migoń, M. Skalska-Zlat, Wrocław 2017.

${ }^{6}$ Encyklopedia popularna PWN, red. W. Baturo, Warszawa 2015.

7 Stownik języka polskiego PWN, red. L. Drabik, Warszawa 2007.

8 M. Robb, New Ways of Reading: The Impact of an Interactive Book on Young Children's Story Comprehension and Parent-Child Dialogic Reading Behaviors, Riverside 2010, s. 36.

9 Ibidem.

10 Ibidem.

11 A. Wier, Multi-sensory interactive books, https://infogram.com/multi-sensory-interactive-books-1g194pk30xev23v [dostęp: 10.03.2018]. 
książek dla dzieci, które wymagają udziału czytelnika. Interakcja ma kluczowe znaczenie dla rozwoju narracji. Interaktywne książki angażują dziecko i pozwalają mu decydować o przebiegu akcji. Wier uważa, że interaktywne książki mogą wykorzystywać nowoczesne technologie, ale nie uznaje tego za warunek konieczny ich funkcjonowania ${ }^{12}$. W tym kontekście definicja samej interaktywności Michała Czajkowskiego, która nota bene pojawia się w publikacji na temat Internetu i cyfryzacji, wydaje się zasadna: „systemy interaktywne przystosowane są do prowadzenia dialogu z obsługującymi je ludźmi - odbierania wprowadzanych przez nich danych lub reagowania na komendy sterujące"13.

Oczywiście książka interaktywna nie jest systemem, ale wskazanie na cechy dialogowe oraz podkreślenie warunku reakcji wpisuje się w jej zadania. Magdalena Howorus-Czajka posługuje się terminem interaktywności, rozważając również relacje, jakie powstają pomiędzy twórcą a odbiorcą ${ }^{14}$. Za Erickiem Zimmermanem podkreśla nierozerwalny udział w procesie czterech form interaktywności: poznawczej, funkcjonalnej, eksplicytnej oraz metainteraktywnej ${ }^{15}$. Te współistniejące odcienie partycypacji prowadzą ku interpretacji dzieła, manifestują funkcjonalne operacje, jakie możemy na nim wykonać, podkreślają nielinearne, hipertekstowe właściwości oraz, dzięki relacji z uczestnikami, budują w przestrzeni (miejskiej, wirtualnej itp.) wydarzenia ${ }^{16}$. Jak słusznie zauważa zatem Howorus-Czajka, ta interaktywność książki wiąże się ściśle z budowaniem kontaktu czytelnika i autora. Zadaniem twórcy staje się stworzenie przestrzeni, w której odbiorca będzie mógł decydować o przebiegu akcji, pobudzać się do kreatywnych działań oraz uruchamiać wyobraźnię.

\section{Próba ustalenia pojęcia „książka interaktywna”}

Anna Sołtysiewicz w artykule na temat książek zabawek, by zrozumieć czym są, podzieliła termin na dwa osobne pojęcia. Przeanalizowała definicje zarówno „książki”, jak i „zabawki”17. W wypadku książki interaktywnej należałoby wykonać ten sam zabieg.

12 Ibidem.

13 M. Czajkowski, Wielka encyklopedia internetu i nowych technologii, Kraków 2002, s. 263.

14 M. Howorus-Czajka, Gra ze sztuką w książce obrazkowej, [w:] Książka obrazkowa. Wprowadzenie, red. M. Cackowska, H. Dymel-Trzebiatowska, J. Szyłak, Poznań 2017, s. 177.

15 E. Zimmerman, Narrative, Interactivity, Play, and Games: Four Naughty Concepts in Need of Discipline, [w:] New Media as Story, Performance, and Game, red. N. Wardrip-Fruin, P. Harrigan, London 2004, s. 32.

16 Ibidem, s. 158.

17 A. Sołtysiewicz, Książki zabawki - definicje i podziat gatunkowy, [w:] Książka, biblioteka, informacja: między podziałami a wspólnotą IV, red. J. Dzieniakowska, M. Olczak-Kardas, Kielce 2015, s. 188-192. 
Istnieje wiele definicji książki, większość z nich wskazuje na jej cechy fizyczne — liczbę stron (w odróżnieniu od broszury) i postać kodeksu [...]. Niektóre definicje uwzględniają to, że książka jest również utrwalonym zapisem myśli ludzkiej, m.in. Wielka Encyklopedia PWN, gdzie określono ją jako [...] „,dokument, w którym na materialnym nośniku są przedstawione za pomocą znaków graficznych komunikaty; jako wytwór kultury materialnej i duchowej książka jest narzędziem utrwalania i przekazu tekstów językowych i pozajęzykowych (obrazowych, symbolicznych)". W Encyklopedii wiedzy o książce podano definicję, która również wskazuje na aspekt formalny książki [...], jak i jej funkcję społeczno-kulturową ${ }^{18}$.

Problemy związane z definiowaniem książki interaktywnej można wiązać ze znaczeniem samego słowa ,interaktywność”, które również nie jest jednoznaczne. Przede wszystkim wśród definicji nie brakuje nawiązań do nowych technologii. Według Stownika języka polskiego PWN: „,interaktywny »o programie komputerowym, sprzęcie elektronicznym itp.: odbierający informacje od użytkownika i reagujący na nie «"19. W Encyklopedii PWN czytamy: „interaktywność, inform. cecha oprogramowania, które oczekuje na reakcje użytkownika, sterujące dalszym wykonaniem programu"20. Można się także przyjrzeć definicji sprzed dynamicznego rozwoju nowych technologii. W Słowniku języka polskiego PWN jeszcze w 1992 roku funkcjonowało następujące sformułowanie: „Interakcja — wzajemne oddziaływanie na siebie osób, przedmiotów, zjawisk; zetknięcie się ze sobą dwóch lub więcej jakichś akcji, działań, dążeń"21.

Warto zauważyć, że ostatnia z wskazanych definicji nie wyklucza udziału urządzeń w procesie lektury książki interaktywnej, ale nie jest to jej koniecznym elementem. Na podstawie zebranych sformułowań można wysunąć dwa wnioski:

1. Książka interaktywna to taka, która wymaga uczestnictwa i interakcji ze strony czytelnika. Pobudza go do kreatywnych działań oraz zostawia pole do interpretacji obrazu i decydowania o rozwoju akcji.

2. Książka interaktywna opiera się na działaniu cyfrowych urządzeń i nowych technologii. Pozwala odbierać i reagować na przekazywaną treść za pomocą hipertekstu i systemów operacyjnych.

Rozwój cyfryzacji wywiera wpływ na różne sfery naszego życia, przedmioty codziennego użytku. Postęp technologiczny nie ominął książek, zwłaszcza tych przeznaczonych dla najmłodszych. Dzieci, które obecnie wychowują się w świecie multimedialnych urządzeń, niemal od urodzenia mają z nimi kontakt. Nadmiar obrazów sprawił, że dzieci są wymagające wobec wizualnych komunikatów. Tradycyjne, drukowane publikacje często nie spełniają ich oczekiwań. Od książki obrazkowej dla najmłodszych wymaga się wielozadaniowości. Powinna bawić, ale i uczyć, być ciekawa pod względem graficznym, nie ujmując przy tym treści, oraz

18 Ibidem, s. 183-184.

19 Interaktywny, [hasło w:] Słownik języka polskiego PWN, https://sjp.pwn.pl/sjp/;2561758 [dostęp: 20.01.2018].

${ }^{20}$ Interaktywność, [hasło w:] Encyklopedia PWN, https://encyklopedia.pwn.pl/haslo/interaktywnosc;3915069.html [dostęp: 20.01.2018].

${ }^{21}$ Interakcja, [hasło w:] Stownik języka polskiego PWN, red. M. Szymczak, Warszawa 1992. 
przekazywać wartości, ale podążać za trendami. Od kilku lat możemy obserwować dynamiczny rozwój książki dziecięcej, która zaskakuje bogactwem nowych rozwiązań edytorskich. Cyfryzacja i technologie — tak ważne dla współczesnego małoletniego czytelnika - powoli przenikają do świata literatury dziecięcej, tworząc nowe, nieznane dotąd kategorie, typy czy podgatunki książek, łączące w sobie wiele funkcji. To już nie tylko publikacje cyfrowe, e-booki i multimedialne zabawki. Wśród nowoczesnych polskich wydawców coraz większym zainteresowaniem cieszą się aplikacje książkowe, które zdominowały zachodni rynek.

Jak tłumaczy Małgorzata Cackowska: „Aplikacja książkowa jest aplikacją multimedialną, która łączy w sobie cechy książki tradycyjnej, ale pozwala na zwiększenie możliwości czytelnika"22 . Za pomocą tabletu czy smartfona możemy konstruować narrację, przenosić bohatera dzieła, poruszać się po przestrzeni, którą znamy z lektury. Zależnie od zaawansowania technologicznego i wieku użytkownika, w stosunku do najmłodszych dzieci aplikacja umożliwia na przykład nagranie głosu rodzica czytającego bajkę, słuchanie podkładu muzycznego do opowieści czy oglądanie animowanego bohatera. Ze względu na te cechy oraz łączenie literatury z nowymi technologiami aplikacja książkowa wpisuje się w założenia książki interaktywnej. Należy jednak pamiętać, że interaktywność nie narzuca obecności urządzeń cyfrowych, że książka interaktywna może przyjmować tradycyjną, papierową formę i pochodzić jeszcze sprzed okresu pierwszych komputerów.

W wypadku najmłodszych dzieci (do szóstego roku życia), by uniknąć problemów z terminologią, która okazuje się za wąska dla pojawiających się gatunków, najczęściej używa się określenia „książka zabawka”. Taki termin dotyczy przedmiotów, które mogą

przybierać kształt przedmiotów lub zwierząt, mają części ruchome, elektroniczne lub mechaniczne. Zwykle można manipulować elementami, układać obrazki, uruchamiać efekty dźwiękowe lub świetlne. Niektóre są pomyślane tak, żeby dziecko współtworzyło książkę poprzez kolorowanie obrazków, uzupełnianie naklejkami tekstu lub ilustracji czy też wykonywanie innych, wskazanych zadań ${ }^{23}$.

Z wielu względów książka interaktywna wpisuje się w tę definicję, ma także wiele cech wspólnych z aplikacją książkową. Po pierwsze — możemy mówić o podobieństwie związanym z rozszerzeniem możliwości typowego kodeksu. Po drugie - książka interaktywna ma pobudzać kreatywność i pozwalać na różne sposoby interpretacji utworu, a po trzecie - pozwala na manipulowanie elementami książki oraz może przybierać różne formy. Doskonałym przykładem książki interaktywnej jest Naciśnij mnie autorstwa Hervé’a Tulleta. Ta bestsellerowa

22 M. Cackowska, Co ma książka obrazkowa do interaktywnej aplikacji książkowej?, „Ryms” 2013, nr 20, s. 2-4.

23 A. Maroń, Ksiązka-zabawka na polskim rynku wydawniczo-księgarskim w PRL-u, [w:] Literatura dla dzieci i młodzieży, t. 4, red. K. Heska-Kwaśniewicz, K. Tałuć, Kraków 2010, s. 296. 
książka opiera się na kilku podstawowych kolorach i kształtach, udając aplikację. „Dosłownie zmusza do interaktywności, zapraszając czytelnika do naciskania kropek i obracania stron w celu sprawdzenia rezultatów" 24 .

\section{Hervé Tullet jako autor współczesnej książki interaktywnej}

Przed rozwojem nowych technologii termin „książka interaktywna” miał zupełnie inne znaczenie. Określano tak między innymi Pat the Bunny Dorothy Kunhardt z $1940 \mathrm{roku}^{25}$. Interaktywne książki rozumiano jako te, które zachęcają dzieci do reagowania, odczuwania i aktywnego odbioru. Odczytując je na głos, interpretując ilustracje i odtwarzając odgłosy ludzi, przedmiotów czy zwierząt, młodzi czytelnicy byli zachęcani do pierwszej lektury.

Zaangażowanie dziecka, zainteresowanie go książką nie zawsze wymaga skomplikowanego przygotowania, dodatkowych elementów czy ruchomych obiektów na stronach. Często nawet niewielkie, proste ilustracje mogą stać się fascynującą rozrywką zarówno dla dziecka, jak i rodzica. Nagrodzona w 2009 roku przez „The New York Times” książka Ice Arthura Geiserta przedstawia opowieść o trzech świnkach, które wyglądają niepozornie, ale za sprawą ilustracji stają się ciekawie poprowadzoną historią. Postacie u Geiserta są interesujące, bo sposób, w jaki je narysowano, pozwala odczytywać ich emocje i zamiary. Dziecko angażuje się w narrację, dostrzegając zmiany na kolejnych stronach — na każdej czytelnik może odkrywać kolejne etapy pracy, poznawać nowe urządzenia i obserwować pracę świnek. To czyni Ice książką interaktywną ${ }^{26}$.

Hervé Tullet opiera się na wielu z omówionych technik, ale prezentuje je w nowoczesnym wydaniu. Stworzenie interaktywnej książki w tradycyjnej formie w czasach, kiedy dzieci od urodzenia otoczone są technologią, to ryzykowna decyzja. Autor tworzy opowieści, które nie tylko nie zawierają w sobie żadnych multimedialnych elementów, ale i ilustracje w nich zawarte nie przedstawiają imponujących postaci, krajobrazów czy przedmiotów. Namalowane jakby ręką dziecka, przy użyciu kilku podstawowych kolorów, zdobyły jednak serca najmłodszych czytelników i oczarowały rodziców.

24 B. Kümmerling-Meibauer, Od niemowląt po dorostych. Europejska ksiązka obrazkowa w nowym tysiącleciu, [w:] Ksiązka obrazkowa..., s. 86.

25 P. Paul, Old-school interactive books, „The New York Times” 20 kwietnia 2011, https:// www.nytimes.com/2011/04/20/books/review/childrens-books-ice-by-arthur-geisert-press-hereby-herve-tullet.html [dostęp: 9.04.2018].

26 Ibidem. 
Un Livre Hervéa Tulleta, znana w Polsce jako Naciśnij mnie, każe zadać pytanie, czym jest i czym powinna być książka interaktywna. Jak podkreśla Bettina Kümmerling-Meibauer:

Udaje bowiem komputerową aplikację — ze stroną niczym ekran dotykowy — dosłownie zmusza do interaktywności, zapraszając czytelnika do naciskania kropek i obracania stron w celu sprawdzenia rezultatów. Podczas gdy dzieci bez dostępu do technologii komputerowej doświadczyłyby tu z pewnością czegoś nowego, Un Livre jest oczywiście stworzona z myślą o czytelnikach, którzy potrafią zrozumieć żart z książki udającej aplikację. W ten sposób naśladowanie przez książkę aplikacji podkreśla często wątpliwą wartość tych opartych na książkach obrazkowych oraz e-bookach. Książka Tulleta wskazuje w tym względzie na poważne zmiany na rynku spowodowane przełomem w cyfrowych książkach obrazkowych ${ }^{27}$.

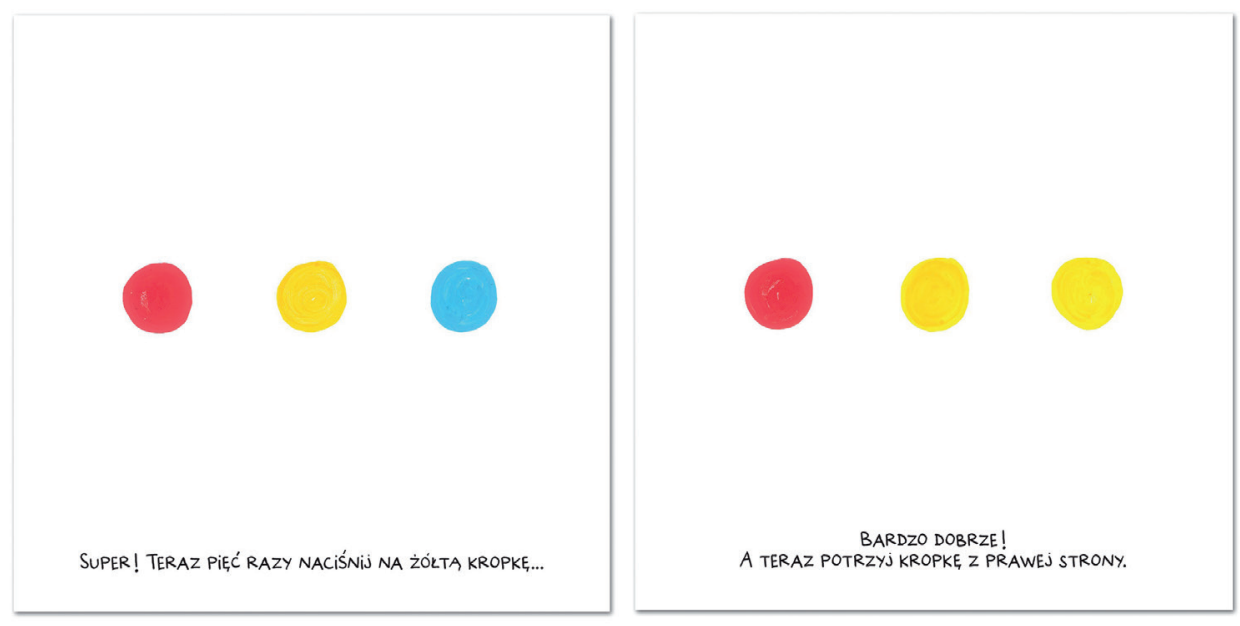

Ilustracja 1. W książkach Hervé'a Tulleta ciężko nie zauważyć podobieństwa do aplikacji Źródło: H. Tullet, Naciśnij mnie, Babaryba, Warszawa 2015.

Kümmerling-Meibauer odwołuje się tylko do jednego przykładu dzieła Tulleta, niemniej większość tytułów tego autora zostało stworzonych według podobnego schematu. Wśród książek francuskiego artysty, które udają aplikacje komputerowe, na pewno należy wymienić także: Figle migle, Kolory czy Och! Ksiażka petna dźwięków. To wydania, które wyglądają bardzo podobnie ze względu na posługiwanie się głównie trzema barwami, podstawowymi kształtami i jednakowym formatem. Na pierwszy rzut oka przypominają zwykłą książkę, ale przy zachowaniu właściwej chronologii - kolejności przewracania stron — czytelnik może mieć wrażenie, że obraz porusza się, zniekształca lub zmienia przy jego udziale. Dotykając ilustracji, wykonując krótkie polecenia autora i przesuwając palce po stronach, dziecko operuje książką podobnie jak aplikacją na tablecie czy smartfonie. W tym miejscu należy jednak zauważyć, że zadaniem książki

27 B. Kümmerling-Meibauer, op. cit. 
interaktywnej nie jest wierne odwzorowanie urządzenia cyfrowego czy systemu komputerowego. Krystyna Zabawa wskazuje, że w XXI wieku nie bez znaczenia w literaturze stają się odwołania do świata Internetu, gier komputerowych i multimediów ${ }^{28}$. Interaktywność w książce analizuje z kolei Aleksandra Mochocka. Badaczka tłumaczy, że ta cecha polega w głównej mierze na wpływaniu, oddziaływaniu na siebie wzajemnie, angażowaniu różnych zmysłów i aktywnym odbiorze przekazywanej treści przez czytelnika ${ }^{29}$. Te zadania na pewno spełniają również inne tytuły Tulleta.

Analizując twórczość artysty, możemy zauważyć, że wiele książek ukazuje się seriami - podobnymi do siebie, opartymi na jednym schemacie. Tak jest w wypadku Turlututu - jednookiego bohatera w koronie, który jest główną postacią w kilku tytułach. Ten dziwny stwór oprowadza młodego czytelnika po książce, angażując go kolejno w zadania, takie jak śpiewanie piosenek, wypowiadanie trudnych słów na głos, szukanie różnic na stronach. Co ważne, Turlututu zwraca się w każdej książce bezpośrednio do odbiorcy — macha, pokazuje i wydaje komendy. Dziecko oswaja się w ten sposób z książką, czuje, że ma wpływ na bieg wydarzeń, i chętniej włącza się w lekturę.

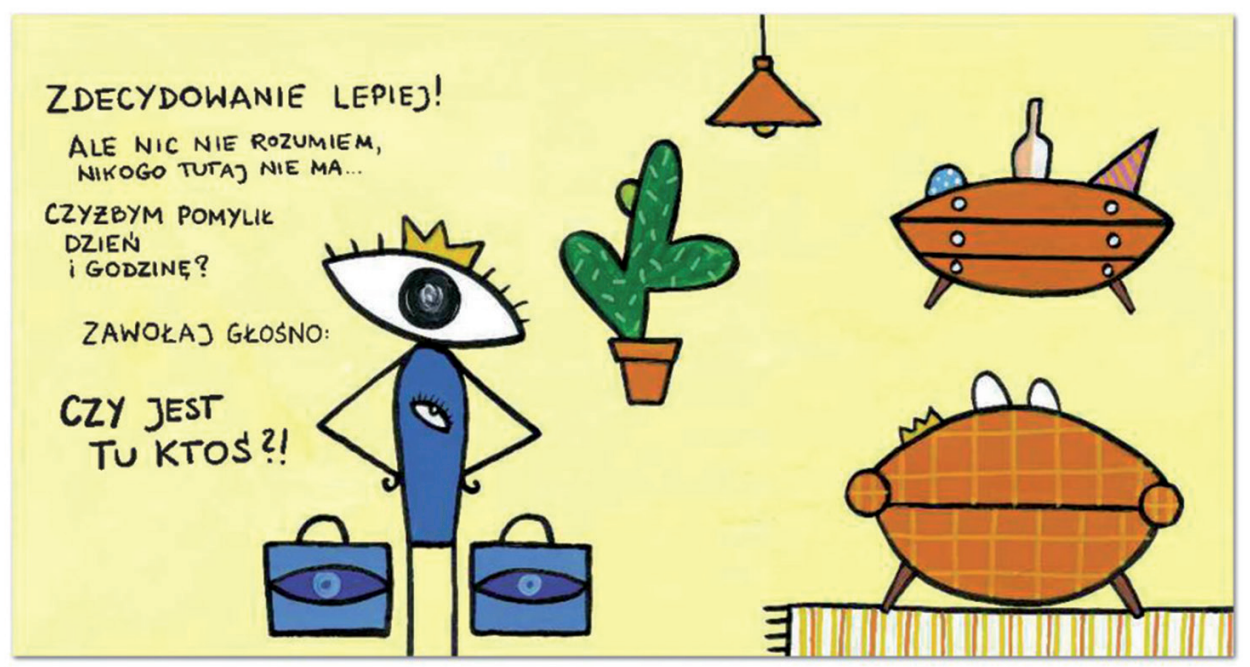

Ilustracja 2. Jeden z głównych motywów serii książek Tulleta. Bohater Turlututu oprowadza dzieci po książce, wydając polecania i komendy, zwracając się bezpośrednio do czytelnika Źródło: H. Tullet, Turlututu. A kuku, to ja!, Babaryba, Warszawa 2012.

${ }^{28}$ K. Zabawa, Wspótczesna literatura dziecięca - propozycje, „Polonistyka. Innowacje” 2016, nr 3, s. 124, https://pressto.amu.edu.pl/index.php/pi/article/view/5559 [dostęp: 9.04.2018].

29 A. Mochocka, Między interaktywnościa a intermedialnością. Książka jako przestrzeń gry, „Homo Ludens” 2009, nr 1, s. 160. 
Tullet konsekwentnie tworzy swoje tytuły przy pomocy podobnych rozwiązań edytorskich: można naciskać, pocierać, stukać i potrząsać książką. Książka $z$ dziura, Paluszkowa olimpiada czy Graj w piłkę to tylko niektóre przykłady tytułów, w których do produkcji wykorzystano metodę sztancowania. Wycinane kształty współgrają z ilustracjami, stając się częścią opowieści, która wymaga od dziecka dodatkowej interakcji. Poza samym oglądaniem stron czytelnik musi na przykład spoglądać przez specjalne otwory, poruszać palcami w wyciętych miejscach czy trafić kulką z papieru do wspomnianej, tytułowej dziury. Rodzic, stając się częścią takiej lektury, może uczestniczyć, czytając poszczególne komendy, natomiast pozostałe zadania przejmuje dziecko.

Kolejnym przykładem interaktywności może być autotematyzm związany z eksponowaniem osoby autora. Jak tłumaczy Krystyna Zabawa: „możliwość osobistego kontaktu z twórcą bywa dla dziecka dużym przeżyciem i dodatkowym bodźcem do poszukiwania i lektury książek właśnie tego pisarza" ${ }^{30}$. W wypadku najmłodszych czytelników bezpośrednie, odautorskie zwroty sprawiają, że dziecko czuje się traktowane poważnie, dzięki czemu całkowicie koncentruje się na książce. W A gdzie tytut? Tullet zabiera czytelników do swojej pracowni, staje się bohaterem własnej opowieści i daje dzieciom możliwość uczestnictwa w fabule. Występujące w książce niedokończone postacie wydają polecenia, dzięki którym czytelnik wciela się w rolę autora - dziecko może rysować po stronach i w kontrolowany sposób decydować o rozwoju wydarzeń.

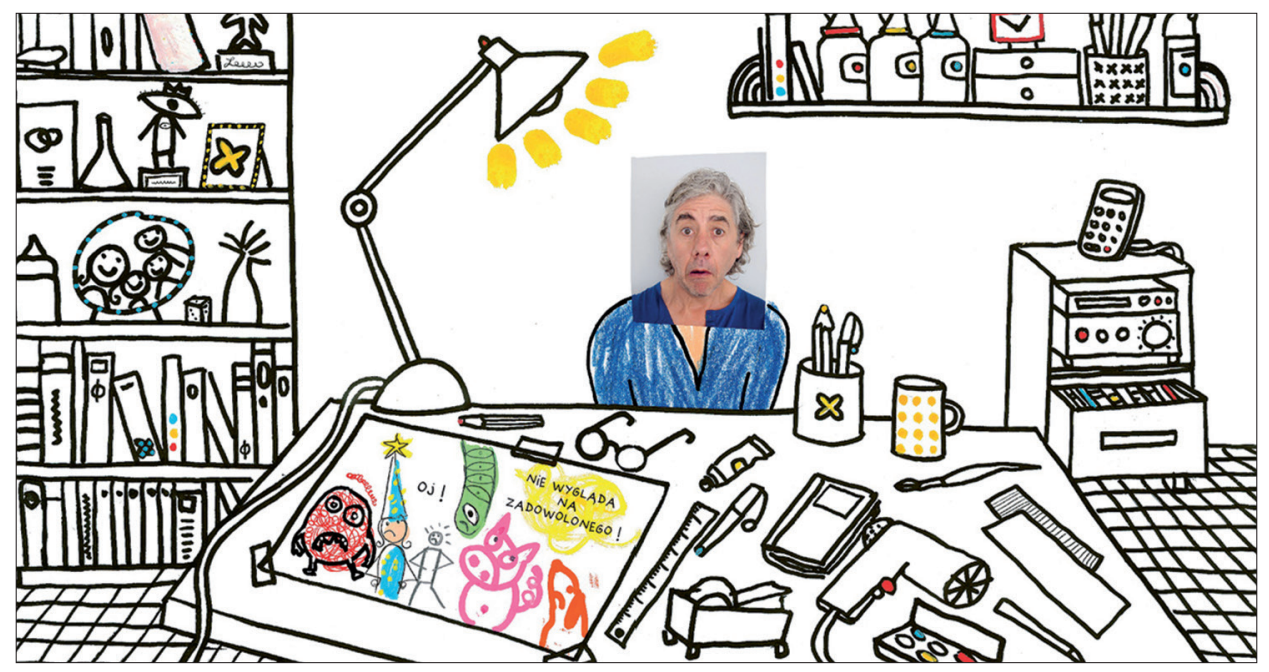

Ilustracja 3. W książce $A$ gdzie tytut? autor staje się jednym z bohaterów fabuły, zachęcając dzieci do udziału w tworzeniu opowieści

Źródło: H. Tullet, A gdzie tytut?, Babaryba, Warszawa 2013.

${ }^{30}$ K. Zabawa, op. cit., s. 126. 
„Dziś pierwsze spotkanie dzieci z książkami obrazkowymi często odbywa się $\mathrm{w}$ formie elektronicznej i na interaktywnych platformach poprzez aplikacje na przenośnych urządzeniach, na przykład: telefonach, androidach i iPadach" 31 . Rozwój technologii nie ominął czytelnictwa. Kiedy na rynek weszły e-booki, wróżono śmierć tradycyjnym książkom. $Z$ czasem okazało się, że niesłusznie, że wciąż chętniej sięgamy po zadrukowane kartki papieru niż nowoczesne urządzenia $^{32}$. Cyfryzacja ma jednak ogromny wpływ na redefiniowanie pojęć, które przed komputerami, tabletami i Internetem miały inne znaczenie. To zjawisko może być przyczyną obecnego statusu książki interaktywnej. W Polsce badacze nie poświęcają jej osobnej uwagi, przez co trudno o jednoznaczną definicję tego pojęcia.

Interaktywność w kontekście cyfrowej książki obrazkowej wyjaśnia Kümmerling-Meibauer ${ }^{33}$. Badaczka zauważa, że w wypadku cyfrowej książki obrazkowej lektura dziecka ,przeistacza się we wspólną, interaktywną czynność, podczas której dzieci zachęcane są do dotykania punktów na ekranie zamiast przewracania kartek". Analogiczne rozwiązanie zastosował w swojej książce Hervé Tullet. Popularne Naciśnij mnie to przecież nic innego jak interaktywne działania wywoływane przez dotykanie kolorowych kropek. Podobnymi narzędziami autor operuje także w innych dziełach. Kolory, 10 razy 10 czy Zabawa z liniami to kombinacje czytania, zabawy i uczenia się (poprzez rysowanie, poznawanie liter, kolorów i liczb, odpowiadanie na proste pytania i powtarzanie odgłosów). Dzieła Tulleta posiadają wiele cech książek konceptowych, a więc aktywnie wpływają na rozwój dziecka i pobudzają jego kreatywność. „Badacze twierdzą, że już poprzez zapoznanie się z książką konceptową dziecko wdraża się w ideę czytelnictwa. Poznaje książkę, która ucieleśnia przecież całe bogactwo kulturowego dziedzictwa"34 — mówi Małgorzata Cackowska w rozmowie Książka jest całym światem.

\section{Definicja współczesnej książki interaktywnej dla dzieci}

Książka obrazkowa to książka, której komunikat skonstruowany jest w dwóch odrębnych systemach znaków: w tekście i obrazie. Tekst tworzony jest przez konwencjonalny system, który odczytywany jest linearnie, natomiast obraz nie jest zbudowany z uniwersalnych i dysjunktywnych jednostek. Mikrojednostkami obrazu są punkty, powierzchnie, linie i kolory. Ich kombinacje w celu wyrażenia czegoś są sprawą indywidualną, ale też w pewnym stopniu uwarunkowaną kulturowo. Obraz jest ikoniczny, ale nie zawsze mimetyczny, naśladujący rzeczywistośćc ${ }^{35}$.

31 B. Kümmerling-Meibauer, op. cit., s. 86.

32 K. Burda, Z papieru wyczytasz więcej, czyli naukowcy o wyższości papierowych ksiazek nad e-bookami, http://www.newsweek.pl/wiedza/nauka/wyzszosc-ksiazki-papierowej-nad-ebookiem-wady-e-bookow-newsweek-pl,artykuly,286327,1.html [dostęp: 10.05.2018].

33 B. Kümmerling-Meibauer, op. cit., s. 90.

34 E. Skibińska, Książka jest całym światem - rozmowa z dr Małgorzata Cackowska, „Ryms” 2016, nr 28, s. 14.

35 K. Hallberg, Literaturoznawstwo a badania nad książka obrazkowa, [w:] Książka obrazkowa..., s. 53. 
Definicja książki obrazkowej Kristin Hallberg odpowiada cechom książek Hervé’a Tulleta. Niezależnie od serii stworzonej przez autora zarówno te koncentrujące się na zmyśle wzroku (Naciśnij mnie), jak i dotyku (Paluszkowa olimpiada) czy słuchu (Och! Książka petna dźwięków) można uznać za książki obrazkowe. W tym miejscu warto jednak podkreślić, że książka obrazkowa nie równa się interaktywnej. Na podstawie przeprowadzonych analiz i wskazanych źródeł można podjąć próbę sformułowania definicji, która zawierałaby najważniejsze cechy i funkcje książki interaktywnej dla dzieci:

Książka interaktywna — odmiana książki obrazkowej, podgatunek książki dla dzieci, który wymaga zaangażowania i interakcji z młodym czytelnikiem. Interakcja ta powinna odbywać się przy pomocy zastosowanych przez autora rozwiązań, które będą wymagały od dziecka wykonania określonych poleceń, działań lub posłużą wywołaniu reakcji. Interakcja w takiej książce zachodzi obustronnie - czytelnik może mieć wpływ na fabułę, wygląd książki i zachodzące w niej zmiany. Z kolei samo dziecko, poprzez pobudzenie kreatywności, może z książką interaktywną się uczyć, bawić i rozwijać. Autor jest przewodnikiem po lekturze, planuje możliwe scenariusze, zachowania i reakcje, które chce wywołać u dziecka. Książka interaktywna często uwzględnia również udział rodzica, towarzyszącego czytelnikowi, pomagającego w nawigacji i czuwającego nad lekturą czy zabawą.

Ustalona w ten sposób definicja ma charakter ogólny i umowny. Wywodzi się z połączenia wcześniej cytowanych definicji słów „,interakcja” i „książka obrazkowa”. Jak tłumaczy Małgorzata Cackowska -

w Polsce badania nad książką obrazkową mają swoją tradycję, ale ich stan nadal można uznać za początkowy. Wiele uwagi poświęca się problemom definicyjnym, wprowadzając zamęt informacyjny. Z pewnością trzeba rzetelnego namysłu nad odmianami książek obrazkowych (na przykład książek konceptowych, wczesnokonceptowych, abecadlników itp.) ${ }^{36}$.

Być może za radą autorki nie należy tak mocno koncentrować się na teoretyzowaniu, a więcej czasu poświęcić badaniom nad nowymi formami książek i ich znaczeniu dla czytelników. Równocześnie, w wypadku książki interaktywnej, konieczne wydaje się ustalenie spójnej definicji, która pozwoliłaby na wyróżnienie tego podgatunku spośród innych i poddanie go szczegółowej analizie.

Według sformułowanej definicji książki interaktywnej Hervé Tullet jest wzorcowym twórcą tego typu publikacji. Jego książki pozwalają dzieciom decydować o fabule (oczywiście w sposób kontrolowany), zmieniać wygląd książki (poprzez dorysowywanie pojedynczych elementów zgodnie z instrukcją) i obserwować zachodzące zmiany (na przykład poprzez pocieranie kolorowych kropek). Dziecko, które ma kontakt z książką interaktywną, jest po niej prowadzone przez autora, ale posiada przy tym szerokie pole do działania. Hervé Tullet zaprasza do samodzielnej interpretacji i nie narzuca jednej drogi odbioru.

${ }^{36}$ M. Cackowska, Współczesna książka obrazkowa - pojęcie, typologia, badania, teorie, konteksty, dyskursy, [w:] Książka obrazkowa..., s. 41. 
„Jedyne niezaangażowane chwile to te, w których niecierpliwe dziecko wyrywa książkę z rąk dorosłego czytelnika. Ale kto może protestować, gdy przedmiotem sporu jest tak elegancko wymyślona książka obrazkowa?"37 — pisze Pamela Paul, recenzując Naciśnij mnie. Trudno się nie zgodzić. Książka interaktywna posiada elementy aplikacji, stosuje analogiczne mechanizmy i spełnia podobne funkcje — niemniej — nadal jest książką. Ciekawą, kreatywną formą i często pierwszym spotkaniem dziecka z literaturą.

\section{Bibliografia}

Burda K., Z papieru wyczytasz więcej, czyli naukowcy o wyższości papierowych ksią̇ek nad e-bookami, http://www.newsweek.pl/wiedza/nauka/wyzszosc-ksiazki-papierowej-nad-e-bookiemwady-e-bookow-newsweek-pl,artykuly,286327,1.html [dostęp: 10.05.2018].

Cackowska M., Co ma książka obrazkowa do interaktywnej aplikacji książkowej?, „Ryms” 2013, nr 20, s. 2-4.

Cackowska M., Czym jest ksiażka obrazkowa? O pojmowaniu ksiażki obrazkowej w Polsce część I, „Ryms” 2009, nr 5, s. 5-6.

Cackowska M., Współczesna książka obrazkowa - pojęcie, typologia, badania, teorie, konteksty, dyskursy, [w:] Ksiażka obrazkowa. Wprowadzenie, red. M. Cackowska, H. Dymel-Trzebiatowska, J. Szyłak, Poznań 2017, s. 11-48.

Czajkowski M., Wielka encyklopedia internetu i nowych technologii, Kraków 2002.

Encyklopedia książki, red. A. Żbikowska-Migoń, M. Skalska-Zlat, Wrocław 2017.

Encyklopedia popularna PWN, red. W. Baturo, Warszawa 2015.

Encyklopedia wiedzy o ksiażce, red. A. Birkenmajer, B. Kocowski, J. Trzynadlowski, Wrocław 1971.

Hallberg K., Literaturoznawstwo a badania nad ksiązka obrazkowa, [w:] Ksiązka obrazkowa. Wprowadzenie, red. M. Cackowska, H. Dymel-Trzebiatowska, J. Szyłak, Poznań 2017.

Howorus-Czajka M., Gra ze sztuka w książe obrazkowej, [w:] Książka obrazkowa. Wprowadzenie, red. M. Cackowska, H. Dymel-Trzebiatowska, J. Szyłak, Poznań 2017, s. 173-190.

Interactive children's book, https://en.wikipedia.org/wiki/Interactive_children\%27s_book [dostęp: 10.03.2018].

Kaplan H., Using interactive books to support early literacy skills, https://www.kaplanco.com/ii/ using-interactive-books [dostęp: 10.03.2018].

Kümmerling-Meibauer B., Od niemowląt po dorostych. Europejska ksiażka obrazkowa w nowym tysiacleciu, [w:] Książka obrazkowa. Wprowadzenie, red. M. Cackowska, H. Dymel-Trzebiatowska, J. Szyłak, Poznań 2017.

Maroń A., Książka-zabawka na polskim rynku wydawniczo-księgarskim w PRL-u, [w:] Literatura dla dzieci i młodzieży, t. 4, red. K. Heska-Kwaśniewicz, K. Tałuć, Kraków 2010.

Mochocka A., Między interaktywnościa a intermedialnością. Książa jako przestrzeń gry, „Homo Ludens" 2009, nr 1, s. 155-176.

Paul P., Old-school interactive books, „The New York Times” 20 kwietnia 2011, https://www.nytimes.com/2011/04/20/books/review/childrens-books-ice-by-arthur-geisert-press-here-byherve-tullet.html [dostęp: 9.04.2018].

Robb M., New Ways of Reading: The Impact of an Interactive Book on Young Children's Story Comprehension and Parent-Child Dialogic Reading Behaviors, Riverside 2010.

37 P. Paul, op. cit. 
Skibińska E., Książka jest całym światem — rozmowa z dr Małgorzatą Cackowska, „Ryms” 2016, nr 28, s. 14.

Stownik języka polskiego PWN, red. L. Drabik, Warszawa 2007.

Sołtysiewicz A., Książki zabawki - definicje i podział gatunkowy, [w:] Książka, biblioteka, informacja: między podziałami a wspólnotą IV, red. J. Dzieniakowska, M. Olczak-Kardas, Kielce 2015, s. 188-192.

Wier A., Multi-sensory interactive books, https://infogram.com/multi-sensory-interactive-books-1g194pk30xev23v [dostęp: 10.03.2018].

Zabawa K., Wspótczesna literatura dziecięca - propozycje, „Polonistyka. Innowacje” 2016, nr 3, s. 124, https://pressto.amu.edu.pl/index.php/pi/article/view/5559 [dostęp: 9.04.2018].

Zimmerman E., Narrative, Interactivity, Play, and Games: Four Naughty Concepts in Need of Discipline, [w:] New Media as Story, Performance, and Game, red. N. Wardrip-Fruin, P. Harrigan, London 2004.

\title{
Contemporary interactive book for children: The example of Hervé Tullet's work
}

\author{
Summary
}

Nowadays, an interactive book is overlooked and forgotten by researchers - it is supplanted by new technologies, applications and multimedia offers from publishers. Lack of definitions leads to problems with its understanding. There are no assumptions about the features, functions and appearance of this subspecies. Placed among both digital solutions and traditional paper editions, it has an unclear status and exists as an undefined subgenre of children's books. The article collects definitions that are analyzed in terms of differences and similarities, contains terminological conclusions about the contemporary interactive book and its current status. Examples from Hervé Tullet's individual works show the characteristics of an interactive book.

KEYWORDS: Hervé Tullet, interactive book, children's book, picture book, interactivity 